\title{
DOES FEEDING SYSTEM INFLUENCE PARASITISM IN BLACK BENGAL
} GOATS IN BANGLADESH?

\author{
A. K. M. A. Rabbi ${ }^{*}$, A. Islam, Anisuzzaman, S. Majumder ${ }^{1}$ and M. H. Rahman \\ Department of Parasitology, Bangladesh Agricultural University \\ Mymensingh-2202, Bangladesh
}

\begin{abstract}
To study the parasitism in goats in relation to different feeding systems, 1110 goats from different areas of Jaypurhat, Tangail, Netrakona and Mymensingh districts were examined. By fecal sample examination, $76.5 \%$ goats were found to be infected with one or more species of endoparasites. In this study, 9 types of helminths' ova were identified such as Fasciola gigantica (14.8\%), Paramphistomum sp. (28.5\%), Schistosoma indicum (3.2\%), strongyles (35\%), Strongyloides sp. (17.4\%), Toxocara spp. (1.5\%), Trichuris sp. (4.6\%), Capillaria sp. (1.2\%) and Moniezia sp. $(3.7 \%)$. Two types of protozoa were also detected, namely, Eimeria sp. $(7.1 \%)$ and Balantidium coli (5.5\%). Along with these, five species of ectoparasites were found: two species were lice such as Damilinia caprae (13.9 \%) and Linognathus vitulli $(4.2 \%)$, and two species were ticks namely, Haemophysalis bispinosa (21.2\%), Rhipicaphalus (Boophilus) microplus (3.6\%) and one species was mite, namely, Demodex sp. (2.9\%). Mean parasitic burden of Paramphistomum sp. $(259.81 \pm 3.35)$ was the highest followed by Eimeria sp. $(224.1 \pm 16.9)$ and Moniezia sp. $(204.9 \pm$ 19.7). Prevalence of helminths and protozoa was significantly $(\mathrm{P}<0.01)$ highest in extensive system $(86.1 \%)$ followed by semi-intensive $(76.3 \%)$ and intensive system (57.5\%). Ova of Schistosoma indicum was absent in the fecal sample of goats of intensive system. Goats of extensive and semi-intensive systems were 4.6 and 2.4 times more susceptible to helminth infection than those of intensive system. Ectoparasitic infestation was the highest in semi-intensive system $(59.7 \%)$ followed by extensive system (33.5\%) and intensive system (8.2\%). In conclusion, the present study suggests that feeding system has a great impact on the prevalence of parasites in Black Bengal goats. Further study can be carried out to determine the effect of parasitism in the production performance of Black Bengal goats.
\end{abstract}

Key Words : Black Bengal Goat, Ectoparasites, Helminths, Feeding system

\section{INTRODUCTION}

The Black Bengal goat is the most common and popular livestock of Bangladesh (Amin et al., 2000). Among the Asian countries, Bangladesh has third highest population of goats

\footnotetext{
1 Department of Agricultural Statistics, Bangladesh Agricultural University, Mymensingh-2202,

*Eskayef Bangladesh Ltd., 158/E Kamal Ataturk Avenue, Banani, Dhaka-1213, Bangladesh
} 
(Amin et al., 2000). Small land requirement and adaptability to harsh climate have made goats more suitable for rearing in our country (Singh et al., 2006). Three types of feeding systems are generally practiced for goat rearing in our country such as extensive (tethering/ free range), intensive (stall feeding), and semi intensive /semi scavenging system. Though goat rearing is very profitable in our country but it is hindered by various problems of which, parasitism is the major one (Jabber and Green, 1983). Mortality of 25\% kids and $43.5 \%$ adult goats occur due to gastrointestinal parasitism in Bangladesh (Rahman et al., 1975). Losses occur due to death of young animals, retarded growth, reduced meat and milk production and delayed maturity (Rahman, 1988). Ectoparasites also contribute to such losses either by sucking blood and/or by causing irritation and discomfort. Additionally, ticks are important vectors and can transmit many pathogens like protozoa, rickettsiae, spirochaets, and viruses to goats (Ghosh et al., 2007).

A wealth of literatures is available on the prevalence, pathophysiological, hematological and immunological aspects of gastrointestinal parasitism in Black Bengal goats (Qadir, 1967; Huq and Shaikh, 1968). But unfortunately, no studies have been conducted to determine the relationship between parasitic infections and different feeding systems in Bangladesh. By considering these points, this study was undertaken to determine the prevalence of parasitic infection in Black Bengal goats under different feeding systems.

\section{MATERIALS AND METHODS}

The study was conducted in four districts such as Jaypurhat, Tangail, Netrakona and Mymensingh. Fecal samples were examined in the Department of Parasitology, Bangladesh Agricultural University, Mymensingh. Only female goats were selected randomly from extensive $(n=534)$, semi-intensive $(n=308)$ and intensive $(n=268)$ systems. The collected fecal samples were brought to the laboratory using 10 percent formal saline in labeled polythene bags. Fecal samples were examined by Stoll's ova counting technique (Colebrook and Wall, 2007). Eggs were identified according to the description given by Soulsby (1982) and Margaret et al. (1994).

Ticks and lice were collected from different parts of the body of individual goat by hand picking. We used small camel hairbrush dipped in ethanol to smear the point of attachment of ticks to preserve the mouthparts and appendages during collection. Ticks and lice were preserved in $70 \%$ alcohol in labelled glass vials after collection. In mite infestations, skin scrapings were collected from the suspected goats and examined under microscope treating with $10 \%$ potassium hydroxide for 20 minutes to dissolve tissue debris. Ticks, lice and mites were identified following descriptions of Hoogostraal (1956) and Soulsby (1982) by preparing permanent slides (Cable, 1957).

Prevalence of parasites was computed according to the method described by Thrusfield (1995). We used the chi-square test for comparing the prevalence of different feeding systems. Odds ratio were computed for comparing the risk of developing parasitic infection in different feeding systems and the confidence intervals were estimated by 
Woolf's method for identifying whether an odds ratio was significant or not (Schlesselman, 1982). F-ratio was used to test the significant difference among the means of parasitic load in various feeding systems (Petrie and Watson, 1999).

\section{RESULTS}

\section{Overall prevalence}

In this study, we found that $76.5 \%$ goats were infected with one or more species of helminthes. Nine types of helminth ova were identified, among them three were trematodes such as Paramphistomum sp. (28.5\%), Fasciola gigantica (14.8\%), Schistosoma indicum (3.2\%), five were nematodes, namely, strongyles (35.0\%), Strongyloides sp. (17.4\%), Trichuris sp. (4.6\%), Toxocara sp. (1.5\%) and Capillaria spp. (1.2\%), and one was cestode, namely, Moniezia sp. (3.7\%). On the other hand, two types of protozoan parasites were identified such as Eimeria sp. (7.1\%) and Balantidium coli (5.5\%) (Table 6). It is evident from Table 1 that the mean parasitic burden of Paramphistomum sp. was the highest (259.81 \pm 3.35$)$ and Capillaria sp. was the lowest (1.2\%).

Table 1. Prevalence and mean burden of helminths and protozoa of Black Bengal goats

\begin{tabular}{lcccc}
\hline \multicolumn{1}{c|}{ Name of parasites } & No. of positive cases & Parasitic load (epg) & Mean \pm SE \\
\hline Strongyles & $389(35 \%)$ & $100-400$ & $173.26 \pm 3.80$ \\
S. papillosus & $193(17.4 \%)$ & $100-400$ & $146.63 \pm 4.65$ \\
T. vitulorum & $17(1.5 \%)$ & $100-500$ & $82.35 \pm 24.61$ \\
T. ovis & $51(4.6 \%)$ & $100-300$ & $52.94 \pm 8.56$ \\
Capillaria sp. & $13(1.2 \%)$ & $100-200$ & $138.46 \pm 14.04$ \\
F. gigantica & $164(14.8 \%)$ & $100-300$ & $131.10 \pm 3.83$ \\
Paramphistomum sp. & $316(28.5 \%)$ & $100-300$ & $259.81 \pm 3.35$ \\
S. indicum & $36(3.2 \%)$ & $100-300$ & $125 \pm 9.24$ \\
M. expansa & $41(3.7 \%)$ & $100-700$ & $204.88 \pm 19.74$ \\
Eimeria sp. & $79(7.1 \%)$ & $100-1000$ & $224.05 \pm 16.92$ \\
B. coli & $61(5.5 \%)$ & $100-400$ & $195.08 \pm 9.18$ \\
\hline
\end{tabular}

Total Number: 1110

We also found that $34.7 \%$ goats were infested with ectoparasites (Table 5). Five species of ectoparasites were identified of which two species were ticks- Haemophysalis bispinosa, Rhipicephalus (Boophilus) microplus, two species were lice- Damilinia caprae, Linognathus vitulli and one specie belonged to mite, namely, Demodex sp. The prevalence of tick infestation in goats was $22.7 \%$, whereas the mite and lice infestation were $2.9 \%$ and $16 \%$, respectively (Table 5). In case of ticks, $H$. bispinosa was predominant (21.2\%), meanwhile in the regard to lice D. caprae was the most common (12.9\%). 


\section{Parasitic infection in goats reared in different feeding system}

There was a significant $(\mathrm{P}<0.01)$ association among the prevalence of helminths and different feeding system at each of the regions. Helminth and protozoan infections were recorded as the highest in extensive system $(86.1 \%)$ followed by semi-intensive $(76.3 \%)$ and intensive (57.5\%) systems (Table 2). It is evident from Table 3 that goats reared under extensive and semi-intensive systems were 4.6 and 2.4 times, respectively more likely to be infected by different helminth parasites than goats reared in intensive system. In extensive system, goats were 1.9 times more susceptible to helminth infection than those of semiintensive system.

Table 2. Prevalence of helminth infections along with their comparison corresponding to various feeding systems at different regions

\begin{tabular}{cll|c|c|c|c}
\hline \multirow{2}{*}{$\begin{array}{c}\text { Name of } \\
\text { region }\end{array}$} & \multicolumn{1}{c|}{$\begin{array}{c}\text { Name of feeding } \\
\text { system }\end{array}$} & \multicolumn{2}{|c|}{ Number of goats } & Prevalence (\%) & $\begin{array}{c}\text { Chi-square } \\
\text { value }\end{array}$ \\
\cline { 3 - 4 } Durgapur & Extensive & 111 & 92 & 82.88 & $12.25^{* *}$ \\
& Semi-intensive & 61 & 47 & 77.05 & \\
& Intensive & 52 & 30 & 57.69 & \\
\hline Madhupur & Extensive & 122 & 101 & 82.79 & $15.67^{* * *}$ \\
& Semi-intensive & 61 & 43 & 70.49 & \\
& Intensive & 55 & 30 & 54.55 & \\
\hline Mymensingh & Extensive & 99 & 91 & 91.92 & $20.89^{* * *}$ \\
& Semi-intensive & 60 & 49 & 81.67 & \\
& Intensive & 52 & 32 & 61.54 & $18.41^{* * *}$ \\
\hline Netrokona & Extensive & 101 & 88 & 87.13 & \\
& Semi-intensive & 61 & 45 & 73.77 & $17.77^{* * *}$ \\
& Intensive & 55 & 31 & 56.36 & \\
\hline Jaypurhat & Extensive & 101 & 88 & 87.13 & $81.61^{* *}$ \\
& Semi-intensive & 65 & 51 & 78.46 & \\
& Intensive & 54 & 31 & 57.41 & \\
\hline Overall & Extensive & 534 & 460 & 86.14 & \\
& Semi-intensive & 308 & 235 & 76.30 & \\
& Intensive & 268 & 154 & 57.46 & \\
\hline
\end{tabular}

${ }^{* *}$ Indicates significant $(\mathrm{P}<0.01)$

Trematode, cestode and protozoan infection were relatively higher in extensive system (44\% 58.4\% and 15.2\%, respectively) (Table 4). The ectoparasitic infestation was significantly $(\mathrm{P}<0.01)$ higher in semi-intensive system $(59.7 \%)$ followed by extensive $(33.5 \%)$ and intensive $(8.2 \%)$ system. The prevalence of strongyles, F. gigantica and S. indicum were significantly $(\mathrm{P}<0.01)$ associated with the feeding systems. A significant 
$(\mathrm{P}<0.05)$ association was also observed between the prevalence of Paramphistomum sp. and the feeding system. The highest prevalence of strongyles (40.1\%), Paramphistomum $\mathrm{sp}$ $(31.8 \%), F$. gigantica $(20.6 \%)$, and S. indicum $(5.4 \%)$ was recorded for extensive system. Prevalence of $S$. indicum was the highest in extensive system (5.4\%) but it was completely absent in intensive system (Table 6).

Table 3. Computation of odds ratio with $95 \%$ confidence interval for comparing the feeding systems with one another at different regions

\begin{tabular}{lcccc}
\hline Name of region & Pairs of comparison of feeding systems & Odds ratio & 95\% Confidence interval \\
\hline Durgapur & E x Vs SI & 1.44 & $0.66-3.12$ \\
& E x Vs I & $3.55^{*}$ & $1.69-7.44$ \\
\hline Madhupur & SI Vs I & $2.46^{*}$ & $1.09-5.54$ \\
\hline E x Vs SI & 2.01 & $0.97-4.14$ \\
& E x Vs I & $4.01^{*}$ & $1.97-8.15$ \\
Mymensingh & SI Vs I & 1.99 & $0.93-4.27$ \\
\hline Netrokona & E x Vs SI & 2.55 & $0.96-6.76$ \\
& E x Vs I & $7.11^{*}$ & $2.85-17.73$ \\
& SI Vs I & $2.78^{*}$ & $1.18-6.57$ \\
\hline Jaypurhat & E x Vs SI & $2.41^{*}$ & $1.07-5.45$ \\
& E x Vs I & $5.24^{*}$ & $2.38-11.54$ \\
& SI Vs I & $2.18^{*}$ & $1.00-4.76$ \\
\hline Overall & E x Vs SI & 1.86 & $0.81-4.27$ \\
& Ex Vs I & $5.02^{*}$ & $2.27-11.10$ \\
& SI Vs I & $2.70^{*}$ & $1.21-6.01$ \\
\hline
\end{tabular}

${ }^{*}$ Indicates significant $(\mathrm{P}<0.05), \mathrm{Vs}=$ Versus, $\mathrm{Ex}=$ Extensive system, $\mathrm{SI}=$ Semi-intensive system, $\mathrm{I}=$ Intensive system

The goats under extensive system and semi-intensive system were about 2 times and 1.5 times, respectively more likely to be infected by strongyles than the goats of intensive system. Goats of extensive system were 1.7 times more susceptible to F. gigantica infection than that of a semi-intensive system. Extensive and semi-intensive systems were 4.7 and 2.7 times respectively more risky for the goats of being infected by F. gigantica than those of intensive system. Under extensive system, the risk of being infected with Paramphistomum sp. was 1.6 times more than that of under intensive system. S. indicim was 2.5 times more likely to infect the goats under extensive feeding system than those of semi-intensive system (Table. 7). In extensive system, mean epg was the highest $289.1 \pm 8.5$ followed by semi-intensive $244.7 \pm 7.7$ and intensive system $221.4 \pm 10.1$. There existed a 
significant $(\mathrm{P}<0.01)$ difference among the mean values of parasitic burden in term of epg. The individual mean parasitic burden of Paramphistomum sp. was highest in all three systems (Table 8 ).

Table 4. Endo parasitic infestation in Black Bengal goat in different feeding systems

\begin{tabular}{l|c|c|c}
\hline \multirow{2}{*}{ Type of parasites } & \multicolumn{3}{|c}{ Prevalence \% (number of positive cases) } \\
\cline { 2 - 4 } & Extensive & Semi-intensive & Intensive \\
\hline Trematodes & $44(235)$ & $39.30(121)$ & $26.90(72)$ \\
Cestodes & $3.60(19)$ & $4.50(14)$ & $3(8)$ \\
Nematode & $58.40(312)$ & $50(154)$ & $39.20(105)$ \\
Protozoa & $15.20(81)$ & $12.70(39)$ & $7.10(19)$ \\
\hline
\end{tabular}

Table 5. Prevalence of ectoparasitic infestation in different feeding systems

\begin{tabular}{l|ccccc|c}
\hline \multirow{2}{*}{$\begin{array}{c}\text { Type of } \\
\text { parasites }\end{array}$} & \multicolumn{4}{|c|}{ Prevalence \% in different systems } & \multirow{2}{*}{$\begin{array}{c}\text { Chi-square } \\
\text { value }\end{array}$} \\
\cline { 2 - 5 } & Extensive & Semi-intensive & Intensive & Prevalence & \\
\hline Tick & 20 & 42.50 & 5.2 & 22.7 & $117.834^{\text {** }}$ \\
Mite & 2.10 & 6.80 & 0 & 2.9 & $26.284^{\text {** }}$ \\
Lice & 15.20 & 28.90 & 3 & 16 & $72.032^{\text {** }}$ \\
Overall & 33.50 & 59.70 & 8.2 & 34.70 & $200.193^{\text {** }}$ \\
\hline
\end{tabular}

**Indicates significant $(\mathrm{P}<0.01)$

Table 6. Parasite wise (helminths and protozoa) prevalence (\%) in different feeding systems

\begin{tabular}{l|c|c|c|c|c}
\hline \multirow{2}{*}{ Name of parasites } & \multicolumn{4}{|c|}{ Prevalence (\%) } & \multirow{2}{*}{$\begin{array}{c}\text { Chi-square } \\
\text { value }\end{array}$} \\
\cline { 2 - 5 } & Ex $(\mathrm{n}=534)$ & $\mathrm{SI}(\mathrm{n}=308)$ & $\mathrm{I}(\mathrm{n}=268)$ & Prevalence & $15.44^{* *}$ \\
\hline Strongyles & $40.07(214)$ & $34.09(105)$ & $26.12(70)$ & 35 & 5.08 \\
S. papillosus & $20.04(107)$ & $15.26(47)$ & $14.55(39)$ & 17.40 & 0.40 \\
T. vitulorum & $1.69(9)$ & $1.62(5)$ & $1.12(3)$ & 1.50 & 2.15 \\
T. ovis & $5.24(28)$ & $4.87(15)$ & $2.99(8)$ & 4.60 & 1.85 \\
Capillaria sp. & $1.12(6)$ & $0.65(2)$ & $1.87(5)$ & 1.20 & $34.58^{* *}$ \\
F. gigantica & $20.60(110)$ & $12.99(40)$ & $5.22(14)$ & 14.80 & $6.93^{*}$ \\
Paramphistomum sp. & $31.84(170)$ & $27.27(84)$ & $23.13(62)$ & 28.50 & $18.05^{\star *}$ \\
S. indicum & $5.43(29)$ & $2.27(7)$ & 0 & 3.20 & 1.03 \\
M. expansa & $3.56(19)$ & $4.55(14)$ & $2.99(8)$ & 3.70 & 4.68 \\
Eimeria sp. & $8.61(46)$ & $6.82(21)$ & $4.48(12)$ & 7.10 & 4.48 \\
B. coli & $6.55(35)$ & $5.84(18)$ & $2.99(8)$ & 5.50 & \\
\hline
\end{tabular}

**Indicates significant $(\mathrm{P}<0.01)$, *indicates significant $(\mathrm{P}<0.05, \mathrm{n}=$ number of goats examined 
Table 7. Computation of odds ratio for the parasitic infections that exhibit significance chi-square value at different feeding systems

\begin{tabular}{l|c|c|c}
\hline Name of parasites & $\begin{array}{c}\text { Pairs of comparison of the feeding } \\
\text { systems }\end{array}$ & Odds ratio & $\begin{array}{c}95 \% \text { confidence } \\
\text { interval }\end{array}$ \\
\hline Strongyles & E x Vs SI & 1.29 & $0.96-1.73$ \\
& E x Vs I & $1.89^{*}$ & $1.37-2.61$ \\
& SI Vs I & $1.46^{*}$ & $1.02-2.09$ \\
\hline F. gigantica & E x Vs SI & $1.74^{*}$ & $1.17-2.58$ \\
& E x Vs I & $4.71^{*}$ & $2.64-8.39$ \\
& SI Vs I & $2.71^{*}$ & $1.44-5.10$ \\
\hline Paramphistomum sp. & E x Vs SI & 1.25 & $0.92-1.70$ \\
& E x Vs I & $1.55^{*}$ & $1.11-2.17$ \\
& SI Vs I & 1.25 & $0.86-1.83$ \\
\hline S. indicum & E x Vs SI & $2.47^{*}$ & $1.07-5.71$ \\
& Ex Vs I & $30.78^{*}$ & $1.87-505.95$ \\
& SI Vs I & 12.47 & $0.70-220.79$ \\
\hline
\end{tabular}

*Indicates significant $(\mathrm{P}<0.05)$

Table 8. Computation of F-ratio for comparing the mean parasitic burden in goats at different feeding systems

\begin{tabular}{lcccc}
\hline Name of parasites & \multicolumn{4}{c}{ Parasitic burden } \\
\cline { 2 - 5 } & Extensive & Semi-intensive & Intensive & F-ratio \\
\hline Strongyles & $183.64 \pm 5.49$ & $170.48 \pm 6.89$ & $145.71 \pm 6.65$ & $7.06^{* *}$ \\
S. papillosus & $155.14 \pm 7.18$ & $140.43 \pm 7.24$ & $130.77 \pm 7.49$ & 2.36 \\
T. vitulorum & $255.56 \pm 29.40$ & $320 \pm 58.31$ & $300 \pm 57.74$ & 0.68 \\
T. ovis & $150 \pm 13.11$ & $160 \pm 13.09$ & $150 \pm 18.90$ & 0.14 \\
Capillaria sp. & $133.33 \pm 21.08$ & $200 \pm 0$ & $120 \pm 20$ & 2.21 \\
F. gigantica & $130.91 \pm 4.79$ & $135 \pm 7.64$ & $121.43 \pm 11.38$ & 0.40 \\
Paramphistomum sp. & $167.65 \pm 4.91$ & $155.95 \pm 5.71$ & $143.55 \pm 6.75$ & $4.03^{*}$ \\
S. indicum & $131.03 \pm 11.21$ & $100 \pm 0$ & 00 & 1.81 \\
M. expansa & $242.11 \pm 29.23$ & $164.29 \pm 16.93$ & $187.50 \pm 12.50$ & 1.68 \\
Eimeria sp. & $243.48 \pm 27.04$ & $180.95 \pm 11.17$ & $225 \pm 32.86$ & 1.25 \\
B. coli & $208.57 \pm 11.86$ & $183.33 \pm 18.52$ & $162.50 \pm 18.30$ & 1.73 \\
Overall & $289.13 \pm 8.45$ & $244.68 \pm 7.86$ & $221.43 \pm 10.13$ & $13.31^{* *}$ \\
\hline
\end{tabular}

**Indicates significant $(\mathrm{P}<0.01)$, *indicates significant $(\mathrm{P}<0.05)$ 


\section{DISCUSSION}

Results of the study indicate that Black Bengal goats of Bangladesh are very much susceptible to ecto and endo parasitic infection. Ndao et al. (1995) and Faye (1988) recorded 100\% parasitic infection in the goat in Senegal and Mauritania, respectively. Huq and Shaikh (1968) examined viscera of sheep and goats and found 90\% infection with gastrointestinal helminth in Bangladesh. Rahman and Mondal (1985) recorded 74\% infestation with $H$. bispinosa and $1 \%$ with $R$. microplus in the goat in Bangladesh. Mondal and Qadir (1978) found that 37.0\% goats were infected with one or more species of Eimeria sp. Kader and Huq (1973) reported $76.6 \%$ of goat's infestated with R. microplus in Bangladesh. These discrepancies among the result of present and earlier studies may be due to the variation in the geographical differences among the experimental niches, metrological differences, sample size, breeds of goats and variation in the husbandry practices. Geo-climatic condition of Bangladesh is favorable for the development and survival of various parasites (Faye et al., 2003; Datta et al., 2004 and Sharkhuu, 2001). In developing countries like Bangladesh, goats are mainly reared by poor people who are not aware of the harmful effects of the parasites (Sertsea and Wossene, 2007). They usually do not follow regular deworming practice. Besides, most of the goats are usually malnourished. The nutritional status of the host can influence the pathogenesis of parasitic infection and it is expected that well-nourished animals withstand parasitism better (Whitlock, 1949). Probably it predominantly plays a vital role in the high parasitic infection rate in Black Bengal goats in Bangladesh.

Findings of the present study suggest that goats reared in extensive system are more susceptible to helminth parasitic infection (86.1\%). Islam and Taimur (2008) examined 224 scavenging Black Bengal goats of Bangladesh for one year and found that $74.50 \%$ goats are infected with helminths. Pandit et al. (2003) had reported higher nematode infections in the field managed sheep $(88.4 \%)$ than the farm managed sheep $(75.9 \%)$ in India. Jagatheesan et al. (2003) conducted a study in India and found that sheep reared in extensive system had higher parasitic load than sheep reared in intensive system. In extensive system, goats are allowed to graze freely in the fields. In our country, there is scarcity of pasture and goats usually graze in the side of cultivable land, by the side of roads and some other fallow lands. So, there is no scope of modern pasture management like alternative grazing, creep grazing and pasture treatment etc. On the other hand, extensive system of the goat rearing is usually practiced in rural areas among poor people (BBS, 1986). They have no idea about the strategic treatment against helminth infections. In fact, deworming is seldom done in village goats in Bangladesh reared under extensive system. In this system, animals are usually malnourished with poor vigor. Malnourished animals are more susceptible to any infection as they are immunocompromised (Lapage 1962). All foresaid factors possibly contribute to the higher parasitic infection in extensive system (Mohanta et al., 2007). In contrast, semi-intensive system of goats rearing is usually practiced in organized farm and some medium holder farmers in peri-urban areas. In this system, goats are not allowed to graze freely in the field rather they are kept in a confined area in which they are provided with restricted grazing in a selective grass field. There is a chance of gaining infection from pasture but obviously, the risk is lower than the extensive 
system. Moreover, deworming was more or less in regular pattern in semi-intensive system. May be due to all these reasons helminth infection was relatively lower in semiintensive system than the extensive system. However, intensive type of the goat rearing is not a common practice, which is mainly seen among more aware and rich people. In this system, goats are not allowed to graze in the field. They are provided with stall feeding. Deworming is regularly practiced that help them in keeping healthy. That is why, the chance of gaining parasitic infection under intensive system was lower than those reared under extensive and semi-intensive system.

An interesting finding was that, infection with $S$. indicum was absent in goats reared under intensive system but it was prevalent other two systems. This result cannot be compared due to paucity of relevant literature. It is well known that Schistosome infection occurs by the skin penetration of cercaria when susceptible animal come in contact with the infected water bodies. Goats reared under extensive and semi-intensive systems may come in contact with open water bodies like ponds, cannels, marshy land. They might got the infection but in intensive system goats are not allowed to forage outside. Therefore, there is a very little chance of coming in contact with the contaminated water bodies with Schistosome cercaria.

On the other hand, ectoparasitic infestation was relatively higher in goats reared under semi-intensive system but these results could not be compared due to unavailability of relevant literatures. However, it can be assumed that in this system, relatively larger numbers of goats are kept in a small confined area which increases the chance of transmission of ectoparasites by direct contact. Contemporarily, in extensive system goats spent most of the time in free-range condition. They roam freely in the fields and usually do not huddle together. Chances of infestation with ectoparasites are relatively lower in extensive system than semi-intensive system. In intensive system, the goats are not allowed to graze freely in the field. They are fully stall fed, well nourished and usually with good health and vigor. Owner of these types of goats are conscious about the health and management practices, even frequently remove ectoparasites from their goats by hand. Therefore, the prevalence of ectoparasitic infestation was lower in intensive system. In conclusion, the present study suggests that feeding system has a great impact on the prevalence of parasites. Their regular deworming and health management are essential.

\section{REFERENCES}

Amin, M. R., Husain, S. S. and Islam A. B. M. M. 2000. Evaluation of Black Bengal goats and their cross with the Jamunapari breed for carcass characteristics. Small Rumin. Res., 38: 211-215.

BBS. 1986. Statistical Pocketbook of Bangladesh, Bangladesh Bureau of Statistics. (Statistics Division), Ministry of Planning, Government of the People Republic of Bangladesh, Dhaka, pp. 258.

Cable, R. M. 1957. An Illustrated Laboratory Manual of Parasitology. $4^{\text {th }}$ edn. Burgess publishing Co., Minneapolis, Minnesota, USA. pp. 45-77. 
Colebrook, E. and Wall, R. 2007. "Ectoparasites of livestockin Europe and the Mediterranean Region." Vetpar, 120: 251-274.

Datta, S., Chowdhury, M. K., Siddiqui, M. A. R. and Karim, M. J. 2004. A retrospective study on the prevalence of parasitic infection in ruminants in selected area of Bangladesh. Vet. J., 38: 25-33.

Faye, D., Leak, S., Nouala, S., Fall, A. and Losson, B. 2003. Effects of gastrointestinal helminth infections and plane of nutrition on the health and productivity of F1 (West African Dwarf $\times$ Sahelian) goat crosses in Gambia. Small Rumin. Res., 50: 153-161.

Faye, G. I. 1988. Gastrointestinal parasites of sheep and goats in the Islamic Republic of Mauritania. Schweizer-Archiv-fur-Tierheilkunde, 130: 43-47.

Ghosh, S., Bansal, G. C., Gupta, S. C., Ray, D., Khan, M. Q., Irshad, H., Shahiduzzaman, M., Seitzer, U., and Ahmed, J. S. 2007. Status of tick distribution in Bangladesh, India and Pakistan. Parasitol Res., 230: 207-216.

Hasan, Z. 1964. Investigation in to the intestinal helminth load in local goats. Indian. Vet. J., 41: 543-546.

Hoogostraal, H. 1956. American Ixodoidea. Vol I. Ticks of the Sudan. $1^{\text {st }}$ edn. Bureau of Medicine and Surgery, Department of Navy. pp. 45-65.

Huq, S. and Shaikh, H. 1968. A survey of helminths parasiting the gastrointestinal tract of goats and sheep in East Pakistan. Pak. J. Vet. Sci., 2: 54-62.

Islam, K. B. M. S. and Taimur, M. J. F. A. 2008. Helminthic and protozoan internal parasitic infections in free ranging small ruminants of Bangladesh. Slov. Vet. Res., 45: 67-72.

Jabber, M. and Green, D. A. G. 1983. The status and potential of livestock within the content of agricultural policy in Bangladesh. The University of Wales. Aberystwyth, United Kingdom. pp. 113.

Jagatheesan, P. N. R., Viswanathan, R. S., Sivakumar, T., Arunachalam, S. and Selvaraju, M. 2003. Parasitic load of Madras Red sheep in different systems of management. Indian J. Small Ruminants, 9: 176-180.

Kader, S. A. and Huq, M. M. 1973. A survey on the prevalence of ticks of sheep and goats in Comilla Kotwali Police Station, Bangladesh. M. Sc. Thesis, Faculty of Veterinary Science. Bangladesh Agricultural University, Mymensingh.

Lapage, G. 1962. Veterinary Parasitology. $2^{\text {nd }}$ edn. Oliver and Boyd, London. pp. 66-723.

Margaret, W. S., Russell, L. K. and Anne M. Z. 1994. Veterinary Clinical Parasitology. $6^{\text {th }}$ edn. Iowa State University Press, Ames, Iowa. pp. 5-93.

Mohanta, U. K., Anisuzzaman, Farjana, T., Das, P. M., Majumder, S. and Mondal M. M. H. 2007. Prevalence, population dynamics and pathological effects of intestinal helminths in Black Bengal goats. Bangl. J. Vet. Med., 5: 63-69.

Mondal, M. M. H. and Qadir A. N. M. A. 1978. A preliminary investigation on the incidence of coccidial infestation in fowl, sheep, goats and cattle. Bang. Vet. J., 12: 7-11. 
Ndao, M., Belot, J., Zinsstag, J. and Pfister, K. 1995. Epidemiology of gastrointestinal helminthiasis in small ruminants from a tree-cropping pasture system. Senegal. Vet. Res., 26: 132-139.

Pandit, B. A., Shardar, R. A., Darzi, M. M., Banday, M. A. A. and Bhat, A. S. 2003. Survey of gastrointestinal nematodes in sheep of Kashmir valley. Indian. J. Small. Ruminants., 9: 39-42.

Petrie, A. and Watson, P. 1999. Statistics for Veterinary and Animal Science. Blackwell Science, UK. pp. 18-85.

Qadir, A. N. M. A. 1967. Investigation on the incidence of gastrointestinal parasites of goats in the East Pakistan Agricultural University Campus. Cey. Vet. J., 15: 58-61.

Rahman, A., Ahmed, M. U. and MIA, A.S. 1975. Studies on the diseases of goats in Bangladesh. Mortality of goats under farm and rural conditions. Trop. Anim. Hlth. Prod. 8: 90.

Rahman, M. H. 1988. Problems of parasitic diseases among domesticated ruminants in Bangladesh. The Veterinarian, 12: 1-4.

Rahman, M. H. and Mondal, M. M. H. 1985. Tick fauna of Bangladesh. Indian. J. Parasitol., 9: 145-149.

Schlesselman, J. J. 1982. Case-Control Studies. Oxford University Press, New York. pp. 174-177.

Sertsea, T. and Wossene, A. 2007. A study on ectoparasites of sheep and goats in eastern part of Amhara region, northeast Ethiopia. Smallrumres., 69: 62-67.

Sharkhuu, T. 2001. Helminths of goats in Mongolia. Vet. Parasitol., 101: 161-169.

Singh, S. K., Singh, M. K. and Singh, N. P. 2006. Role of goats in sustainable rural livelihoods in India. Proceedings of the APHCA-ILRI Regional Workshop on Goat Production Systems and Markets, 24 - 25 October. Luang Prabang, Laos. pp. 5-8.

Sinha, A. K. and Sahai B. N. 1973. On incidence and nature of helminthic infections in goats in Bihar. Indian. J. Anim. Health., 12: 11-12.

Soulsby, E. J. L. 1982. Helminths, Arthropods and Protoza of domesticated Animals. $7^{\text {th }}$ edn. Bailliere Tindall, L. London. pp. 136-778.

Thrusfield, M. 1995. Veterinary Epidemiology. 2nd edn, Blackwell science, USA. pp. 39-41.

Whitlock, J. H. 1949. The relationship of nutrition to the development of trichostrongyloides. Cornell Veterinarian., 39: 146-182. 